\title{
A unified political trajectory
}

Since reunification, Germany has witnessed significant scientific development almost regardless of the party in charge. The forthcoming election offers smooth continuation and important challenges, whoever wins.

A s German citizens prepare to go to the polls, it is worth reflecting on the state of German research when the country was reunified 12 years ago by Chancellor Helmut Kohl, head of the long-standing Christian Democrat-Free Democrat coalition. The inward-looking East German Academy of Sciences employed tens of thousands of researchers, all secure in their jobs but producing little research that could be considered internationally competitive. The comfortable academic research organizations in the west employed hundreds of thousands of researchers, most of them secure in their jobs, and producing very good, internationally competitive research - although not enough to have justified their generous budgets.

The task of closing the vast gap in science policy began. The academy was duly dissolved, and huge investment was made in research structures in the east which were newly created in the image of those in western Germany. The widely acknowledged stodginess of the west also had to be tackled, to convert the over-bureaucratized, overhierarchical, over-regulated research environment into something much more responsive and flexible. The Zeitgeist dictated also that closer links between academia and industry be forged.

Much of this has been achieved, and independently of party lines. Kohl's coalition, which enjoyed two legislative periods after reunification, started the process. Its successor, Gerhard Schröder's Social Democrat-Green coalition, continued it. The next government and at the moment it is anyone's guess what its political shade will be — will almost certainly continue on the same trajectory.

\section{Stronger force}

The notorious laws that opposed genetic technologies, and that made working with modified genes nigh-on impossible, were liberalized by successive governments during the 1990s, and are now in line with those of other Western countries. In 1996, Christian Democrat research minister Jürgen Rüttgers introduced his astonishingly successful BioRegio competition, which brought together academic and industrial scientists to plan the best regional biotechnology initiatives. The time was ripe: the competition evidently succeeded (despite the lack of a tangible prize) because biotechnology has boomed in Germany ever since. The Social Democrats extended the BioRegio idea to an initiative to promote high-tech research in the new Länder.

In 2001, Social Democrat research minister Edelgard Bulmahn introduced laws to make academic salary scales more flexible, so higher salaries could be paid to top researchers, and introduced 'junior professorships', which give young researchers academic freedom at an earlier age. All this will help Germany to compete internationally for top researchers, and will help to break down stifling hierarchies. The main parties all want to extend this flexibility to all levels of research by giving universities the autonomy to hire and fire scientists.

The changes have made Germany an even stronger force in research than it was. Already a respectable second place in European scientific-publication league tables in 1994, behind the United Kingdom, the gap has since narrowed. According to the latest European Union (EU) science indicators, Germany had the largest annual growth in the number of publications of all the large research nations, including Japan and the United States.
The credit for revitalizing Germany's research base cannot be claimed by one political party. Whoever wins the election on $22 \mathrm{Sep}-$ tember, scientists will notice few major changes in their working lives, although nuclear-energy researchers would doubtless be pleased by the Christian Democrats' commitment to invigorate their discipline after a period in the doldrums under the Social Democrat-Green coalition. The gap in science policy, so wide in 1990, is now minuscule.

\section{Moral issues}

But some problematic aspects of Germany's landscape have stubbornly resisted the best efforts of political parties and scientists, to the detriment of German research. In particular, German universities remain unattractive to foreigners, particularly those in eastern Germany, despite their well-equipped labs and attempts to reduce the notorious bureaucratic hurdles for guest scientists. Only around $10 \%$ of European postdoctoral researchers holding an EU Marie Curie Fellowship, which enables young scientists to study in another EU country, choose to go to Germany; one-third go to the United Kingdom and $17 \%$ to France.

Other obstacles to science are matters of politicians' and voters' principles. Deep moral concerns over issues such as the use of human embryonic stem cells in research will continue to put the brakes on some areas of front-line research, whichever party wins, despite enlightened and sensitive arguments to the contrary (see, for example, Nature 412, 479; 2001). The Christian Democrats' candidate research minister, Annette Schavan, is expected to follow in the footsteps of current minister Edelgard Bulmahn, who has ignored the call of many scientists for a more liberal approach. With all-party support, a law was passed earlier this year banning the use of human embryonic stem cells, with only a few exceptions. And Germany's determined stance has forced a block on the funding of such research in the EU's next Framework research programme.

The main parties are also united in their attitude to research on animals. Although the number of bureaucratic hurdles through which researchers must jump to use animals has been reduced, the Christian Democrats this year abandoned their resistance to a constitutional amendment, which now gives animals rights to be protected by the state. This gives plenty of ground for animal-protection groups to challenge researchers in constitutional courts.

The issue that is most likely to be affected by the election outcome is 'green biotech'. Agricultural biotechnology has always had a rough ride in Germany, but the Christian Democrats and the Social Democrats are both quietly bullish about promoting it. The Social Democrats have been held back by their coalition partner, the Greens. A coalition without the Greens would constitute a government more friendly to genetic modification.

As the political campaigns gather momentum, science is absent from the debates - surprising, perhaps, given the intense concentration of politicians and the media on the issue of human embryonic stem cells throughout the past year. The parties are focusing on the more immediate issues of unemployment, flood damage and Iraq. German scientists, faced with a scientifically neutral choice, can vote according to their political beliefs. 